\title{
Oxidative stress in skin fibroblasts cultures from patients with Parkinson's disease
}

\author{
Pilar del Hoyo ${ }^{1}$, Alberto García-Redondo ${ }^{1}$, Fernando de Bustos², José Antonio Molina ${ }^{3}$, Youssef Sayed ${ }^{4}$, \\ Hortensia Alonso-Navarro ${ }^{4,5}$, Luis Caballero², Joaquín Arenas', José AG Agúndez ${ }^{6}$, Félix Javier Jiménez-Jiménez ${ }^{4,7^{*}}$
}

\begin{abstract}
Background: In the substantia nigra of Parkinson's disease (PD) patients, increased lipid peroxidation, decreased activities of the mitochondrial complex I of the respiratory chain, catalase and glutathione-peroxidase, and decreased levels of reduced glutathione have been reported. These observations suggest that oxidative stress and mitochondrial dysfunction play a role in the neurodegeneration in PD. We assessed enzymatic activities of respiratory chain and other enzymes involved in oxidative processes in skin fibroblasts cultures of patients with PD.
\end{abstract}

Methods: We studied respiratory chain enzyme activities, activities of total, Cu/Zn- and Mn-superoxide-dismutase, gluthatione-peroxidase and catalase, and coenzyme Q10 levels in skin fibroblasts cultures from 20 Parkinson's disease (PD) patients and 19 age- and sex- matched healthy controls.

Results: When compared with controls, PD patients showed significantly lower specific activities for complex $\mathrm{V}$ (both corrected by citrate synthase activity and protein concentrations). Oxidized, reduced and total coenzyme Q10 levels (both corrected by citrate synthase and protein concentrations), and activities of total, Cu/Zn- and Mnsuperoxide-dismutase, gluthatione-peroxidase and catalase, did not differ significantly between PD-patients and control groups. Values for enzyme activities in the PD group did not correlate with age at onset, duration, scores of the Unified Parkinson's Disease Rating scales and Hoehn-Yahr staging.

Conclusions: The main result of this study was the decreased activity of complex $V$ in PD patients. This complex synthesizes ATP from ADP using an electrochemical gradient generated by complexes I-IV. These results suggest decreased energetic metabolism in fibroblasts of patients with PD.

\section{Background}

The pathogenesis of the neuronal degeneration of neurons in the pars compacta of the substantia nigra in patients with Parkinson's disease (PD) is unknown. The discovery that the 1-methyl-4-phenyl-pyridinium ion $\left(\mathrm{MPP}^{+}\right)$, the metabolite of the parkinsonism-inducing neurotoxin 1-methyl-4-phenyl-1,2,3,6-tetrahydropyridine (MPTP) did inhibit complex I [1-3] led some investigators to examine the mitochondrial function in idiopathic PD.

The mitochondrial respiratory chain consists of five enzymatic complexes located within the inner mitochondrial membrane. Four enzymes (complexes I-IV) transport electrons from $\mathrm{NADH}$ or succinate to oxygen,

\footnotetext{
* Correspondence: fjavier.jimenez@salud.madrid.org

${ }^{4}$ Departamento de Medicina-Neurología. Hospital. "Príncipe de Asturias",

Universidad de Alcalá, Alcalá de Henares, Madrid, Spain

Full list of author information is available at the end of the article
}

and these complexes pump protons out of the mitochondria to form an electrochemical gradient. Complex V (ATP synthase) uses that electrochemical gradient to synthesize ATP from ADP.

Many studies have shown decreased complex I activity in the substantia nigra of PD patients (reviewed in reference [4]). More recently, Parker et al. [5] found decreased complex I activity in frontal cortex as well. However, the results of studies measuring mitochondrial complexes in peripheral tissues have been controversial (reviewed in reference [4]). The activity of mitochondrial complexes has been measured in the following tisues:

- Skeletal muscle (most studies performed with isolated mitochondria). There have been reported normal activities of mitochondrial respiratory chain complexes I-IV [6-10], or decreased activities of complexes I [11-16], II [11-14] or IV [15-17]. 
- Platelets (most studies performed with isolated mitochondria). There have been reported normal activities [6,18-20], or decreased activities of complex I [21-26], complex II+III [25] or complex IV [24].

- Lymphocytes. Studies with homogenates showed decreased activities of complex II [23] or complexes I and IV [27], while studies with isolated mitochondria showed normal activities [28], or decreased activity of complexes I and I+III [29], and complex IV [29].

- Leukocytes: Muftuoglu et al. [30] reported decreased complexes I and IV activities in leukocytes from patients with idiopathic PD, and decreased complex I activity, with normality of complex IV, in patients with parkin mutations.

- Spermatozoa. Our group showed similar mitochondrial respiratory chain enzymes activities corrected by citrate synthase (CS), in the spermatozoa from untreated PD patients [31].

A study on mitochondrial function of skin fibroblasts from PD showed a deficiency in complexes I and IV $[32,33]$ that was partially restored with coenzyme $Q_{10}$ treatment [33]. Piccoli et al. [34] examined mitochondrial respiratory function of a patient affected by earlyonset parkinsonism carrying the homozygous W437X nonsense mutation in the PINK1 gene, and found decreased complex IV activity and some depression of the ATPase activity. In a recent study, Ferrer et al. [35] have shown decreased levels of ATP synthase in the substantia nigra and increased levels in the frontal cortex of patients with PD.

The study of mitochondrial function in PD might be important because, together with the classical description of oxidative stress and mitochondrial dysfunction in the brains of patients with this disease, the identification of specific gene mutations that cause PD has reinforced their relevance. Proteins associated with familial PD, such as PTEN-induced putative kinase 1 (PINK1), DJ-1, alpha-synuclein, leucine-rich repeat kinase 2 (LRRK2) and, possibly, parkin, are either mitochondrial proteins or are associated with mitochondria, and have a role on oxidative stress [36].

Some authors described decreased activities of the antioxidant enzymes glutathione-peroxidase (GPx) [37,38], total superoxide-dismutase (SOD) [39], MnSOD [40], Cu,Zn-SOD [41], and catalase [37], in the substantia nigra of PD patients; while Mn-SOD activity in the cortex of PD patients has been found increased $[35,42]$. GPx activity has been studied in serum or plasma, erythrocytes, and neutrophils; total SOD, $\mathrm{Cu}$, $\mathrm{Zn}$-SOD and/or Mn-SOD levels or activities in serum or plasma, cerebrospinal fluid, erythrocytes, neutrophils, platelets, and lymphocytes; and catalase activity in erythrocytes from PD patients. The results of these studies (reviewed in reference [4]) are controversial. Piccoli et al. [34], in their patient with the homozygous W437X nonsense mutation in the PINK1 gene described normal levels of total glutathione, reduced glutathione and glutathione peroxidase activity, normal $\mathrm{Cu} / \mathrm{Zn}-\mathrm{SOD}$ activity and a small decrease of the mitochondrial Mn-SOD in fibroblasts. To our knowledge activity of catalase has not been studied previously in fibroblasts.

Coenzyme $\mathrm{Q}_{10}\left(\mathrm{CoQ}_{10}\right)$ is the electron acceptor for mitochondrial complexes I and II and a powerful antioxidant [43]. Shults et al. [44] reported a correlation between mitochondrial $\mathrm{CoQ}_{10}$ levels and activities of complexes I and II/III. Gotz et al. [45] reported a decreased [reduced CoQ10/oxidized CoQ10] ratio (redox ratio) in untreated PD patients, that was further decreased by levodopa treatment and partially restored with selegiline. Serum or plasma $\mathrm{CoQ}_{10}$ levels have been described decreased, normal or increased in some studies (reviewed in reference [4]). To our knowledge, $\mathrm{CoQ}_{10}$ levels in fibroblasts of PD patients have not been measured previosly.

The aim of this study was to assess the enzymatic activities of respiratory chain enzymes and other enzymes involved in oxidative processes, such as GPx, SOD, catalase and coenzyme $\mathrm{Q}_{10}$ in skin fibroblast cultures from patients with PD. The study was carried out in skin fibroblasts because the specimens were easily accessible and should be free of influence from medication, environmental hazards and other possible factors contributing to oxidative stress.

\section{Methods}

\section{Patients and controls}

Twenty patients diagnosed with PD and 19 healthy ageand sex-matched controls were enrolled in this study, after informed consent. The study was approved by the Ethics Committees of the University Hospitals "Doce de Octubre" and "Príncipe de Asturias", and was conducted according to the declaration of Helsinki. Two patients received no treatment, while the other 18 were treated with antiparkinsonian drugs alone or in combination including levodopa (16 cases), dopamine agonists (14 cases), selegiline or rasagiline (8 cases), anticholinergics ( 3 cases), and amantadine (1 case).

The control group was composed by 19 patients evaluated in the neurology departments of the same hospitals because of tension type headache, dizziness, dorsolumbar or cervical pain, etc. The clinical data of PD patient and control groups are summarized in table 1 .

The following exclusion criteria were applied both to patients and controls: A) Ethanol intake higher than 80 g/day in the last 6 months. B) Previous history of 
Table 1 Clinical data of Parkinson's disease (PD) and control patients groups

\begin{tabular}{llll}
\hline VARIABLE & PARKINSON'S DISEASE $(\boldsymbol{n}=\mathbf{2 0})$ & CONTROLS $(\boldsymbol{n}=\mathbf{1 9})$ & $\boldsymbol{p}$ values \\
\hline MEAN (SD) AGE (years) & $59.2(15.6)$ & $59.16(10.7)$ & $\mathrm{n} . \mathrm{s}$ \\
SEX (F/M) & $8 / 12$ & $13 / 7$ & \\
MEAN (SD) AGE AT ONSET OF PD (years) & $51.1(10.2)$ & & \\
MEAN (SD) DURATION OF PD (years) & $8.1(4.2)$ & & \\
\hline
\end{tabular}

chronic hepatopathy or diseases causing malabsorption. C) Previous history of severe systemic disease. D) Atypical dietary habits (diets constituted exclusively by one type of foodstuff, such as vegetables, fruits, meat, or others, special diets because of religious reasons, etc) F) Intake of drugs which modify lipid absorption. G) Therapy with vitamin supplements in the last 6 months.

\section{Skin fibroblast cultures}

Human skin fibroblasts were obtained from the dorsal region of the upper arm of each PD patient or control. Fibroblasts from the biopsy specimens were cultured in Dulbecco's modified Eagle's medium containing penicillin (100 UI/mL), streptomycin (100 mg/dl), L-glutamine (4 $\mathrm{mM}$ ) and supplemented with heat-inactivated fetal calf serum at $37^{\circ} \mathrm{C}$ in a humidified atmosphere of $95 \%$ air and $5 \% \mathrm{CO}_{2}$. Cells were grown to confluence, harvested by trypsinization at $37^{\circ} \mathrm{C}$, washed with culture medium and resuspended with phosphate buffer $20 \mathrm{mM}$, and then sonicated to obtain the cell homogenate. Care was taken not to use cultures with a passage number greater than 12 .

\section{Respiratory chain enzymes assay}

Respiratory chain enzymes and citrate synthase activity were measured in a DU-68 spectrophotometer (Beckman), applying 35-150 $\mu \mathrm{g}$ of total protein per $1 \mathrm{ml}$ test volume in every complex enzyme assay. Incubation temperatures were $30^{\circ} \mathrm{C}$ for $\mathrm{NADH}$ coenzyme $\mathrm{Q}$ oxidoreductase (complex I), rotenone-sensitive $\mathrm{NADH}$ cytochrome c reductase (complexes I and III), succinate cytochrome c reductase (complexes II and III), succinate dehydrogenase (complex II) and citrate synthase (CS), and $38^{\circ} \mathrm{C}$ for cytochrome c oxidase (complex IV). The activities of complexes II, I and III, II and III, IV, and CS were determined as reported elsewhere [27]. Complex I was measured by following the oxidation of $\mathrm{NADH}$ at $340 \mathrm{~nm}$ in $100 \mathrm{mM}$ Tris- $\mathrm{HCl} \mathrm{pH} \mathrm{7.4,500}$ $\mathrm{mM}$ sucrose, $2 \mathrm{mM}$ EDTA, $5 \mathrm{mM} \mathrm{KCN}, 100 \mu \mathrm{M}$ $\mathrm{NADH}$, and $50 \mu \mathrm{M}$ DB (2,3-dimethyl-5-decyl-6-methylbenzoquinone) [46]. The reaction was inhibited by $90 \%$ when $2 \mu \mathrm{M}$ rotenone was present. Complex V was determined by measuring $2.5 \mathrm{mM}$ ATP extinction in a mean with $50 \mathrm{mM}$ Hepes-Mg buffer at $\mathrm{pH} 8.0,0.2 \mathrm{mM}$ $\mathrm{NADH}$, and phosphoenol-pyruvate $2.5 \mathrm{mM}$, and then adding $5 \mu \mathrm{l}$ of pyruvate-kinase $(10 \mathrm{mg} / \mathrm{ml})$ and $10 \mu \mathrm{L}$ of lactate-dehydrogenase $(5 \mathrm{mg} / \mathrm{ml})$ in presence of $10 \mu \mathrm{l}$ of antimycin A $(0.2 \mathrm{mg} / \mathrm{ml}$ in $50 \%$ ethanol). The oligomycin sensitive fraction was measured by adding $10 \mu \mathrm{l}$ of oligomycin $(0.2 \mathrm{mg} / \mathrm{ml}$ in $50 \%$ ethanol). To correct for mitochondrial volume, all respiratory chain enzyme activities were normalized to the activity of CS. Protein were measured by the method of Lowry et al. [47]. Specific activities were expressed as $\mathrm{nmol} \times \mathrm{min}^{-1} \mathrm{xmg}$ protein $^{-1}$, and referred to the specific activities of CS to correct for mitochondrial volume. All chemicals were from Boehringer Mannheim (Boehringer Mannheim, Germany) and Sigma Chemicals (St. Louis, MO). The measures were performed three times for every sample on three different passages (most of them between passage 5 and passage 10). The standard deviation of every measure is specified in table 2 . The range of linearity was defined in all our determinations in a wide range of

Table 2 Mean (SD) respiratory chain enzymes activities (expressed as $\mathrm{nmol} / \mathrm{min} / \mathrm{mg}$ protein) in skin fibroblast cultures of patients with Parkinson's disease (PD) and controls (CS = citrate synthase)

\begin{tabular}{|c|c|c|c|}
\hline VARIABLE & $\begin{array}{l}\text { PARKINSON'S DISEASE } \\
(n=20)\end{array}$ & $\begin{array}{l}\text { CONTROLS (n } \\
=19)\end{array}$ & $\begin{array}{l}p \\
\text { values }\end{array}$ \\
\hline COMPLEX I/CS & $34.56(17.10)$ & $26.13(9.49)$ & n.s. \\
\hline COMPLEX II/CS & $19.02(3.22)$ & $17.10(2.77)$ & n.s. \\
\hline $\mathrm{SDH} / \mathrm{CS}$ & $14.45(2.83)$ & $12.71(3.35)$ & n.s \\
\hline COMPLEX III/CS & $26.80(7.97)$ & $26.75(5.86)$ & n.s. \\
\hline COMPLEX IV/CS & $65.70(10.83)$ & $62.01(9.61)$ & n.s. \\
\hline COMPLEX V/CS & $41.57(16.70)$ & $52.52(23.56)$ & 0.021 \\
\hline COMPLEX I + III/CS & $380.70(88.90)$ & $337.91(58.85)$ & n.s. \\
\hline $\begin{array}{l}\text { COMPLEX II + III/ } \\
\text { CS }\end{array}$ & $16.67(5.03)$ & $12.27(3.33)$ & n.s \\
\hline CS/protein & 77.39 (28.59) & $74.27(20.08)$ & n.s \\
\hline COMPLEX I/protein & $26.70(11.13)$ & $22.48(9.96)$ & n.s. \\
\hline $\begin{array}{l}\text { COMPLEX II/ } \\
\text { protein }\end{array}$ & $13.73(3.79)$ & $13.22(3.70)$ & n.s. \\
\hline SDH/protein & $10.07(2.85)$ & $10.17(3.70)$ & n.s. \\
\hline $\begin{array}{l}\text { COMPLEX III/ } \\
\text { protein }\end{array}$ & $20.82(9.20)$ & $20.10(7.51)$ & n.s. \\
\hline $\begin{array}{l}\text { COMPLEX IV/ } \\
\text { protein }\end{array}$ & $44.49(10.53)$ & $44.49(11.42)$ & n.s. \\
\hline $\begin{array}{l}\text { COMPLEX V/ } \\
\text { protein }\end{array}$ & $29.95(14.70)$ & $42.21(18.80)$ & 0.017 \\
\hline $\begin{array}{l}\text { COMPLEX I + III/ } \\
\text { protein }\end{array}$ & $253.76(79.91)$ & $247.25(51.31)$ & n.s. \\
\hline $\begin{array}{l}\text { COMPLEX II + III/ } \\
\text { protein }\end{array}$ & $9.89(3.11)$ & $9.48(4.59)$ & n.s. \\
\hline
\end{tabular}


protein concentration. So we decided to use the homogenates in order to have a total protein concentration of 35-150 micrograms per mililiter of final test volume. This range was inside the linearity to all the activities of the OXPHOS complexes.

\section{Glutathione-peroxidase, catalase and superoxide- dismutase isoenzymes determination}

Glutathione peroxidase specific activity was determined according to the method described by Flohé and Günzler [48] based on NADPH oxidation followed at 340 nm at $37^{\circ} \mathrm{C}$.

Catalase activity was determined according to the method described by Aeby [49] based on $\mathrm{H}_{2} \mathrm{O}_{2}$ decomposition followed at $240 \mathrm{~nm}$ at room temperature. Catalase specific activity was determined by calculating the rate constant of a first order reaction.

Total and Mn-SOD activities were determined according to the method described by Spitz and Oberley [50] based on nitroblue tetrazolium reduction by superoxide radicals followed at $560 \mathrm{~nm}$ at room temperature. The $\mathrm{Mn}-\mathrm{SOD}$ was distinguished from cyanide-sensitive $\mathrm{Cu} /$ $\mathrm{Zn}$-SOD by the addition of $5 \mathrm{mM} \mathrm{NaCN}$. Cu/Zn-SOD activity was calculated by substracting the cyanide-resistant SOD activity form the total SOD activity. One unit of SOD activity is defined as the amount of enzyme that inhibits the reaction rate by $50 \%$.

All enzymatic activities were expressed as values normalized to total cellular protein. The measurements were performed three times for every sample.

\section{Coenzyme $\mathbf{Q}_{10}$ determinations}

Oxidized, reduced and total coenzyme $\mathrm{Q}_{10}$ levels were determined by high performance liquid chromatography with electrochemical detection. The method used was that of Langedijk et al. [51] with some modifications. The stationary phase was a reverse phase column (HR-80 RP$\mathrm{C}_{18}, 80 \times 4,6 \mathrm{~mm}$. ESA Inc). The mobile phase was prepared by dissolving $7 \mathrm{~g}$ of $\mathrm{NaClO}_{4} \cdot \mathrm{H}_{2} \mathrm{O}$ in $1000 \mathrm{ml}$ of methanol/propanol/ $\mathrm{HClO}_{4}$ 70\%, 700.8:200:0.2 ( $\mathrm{vol} / \mathrm{vol}$ ), and the flow rate was set at $0.8 \mathrm{ml} / \mathrm{min}$. The programmed conditions for the electrochemical detector and the postcolumn valve were the same. The system was entirely controlled by a computer (Kromasystem 2000, Kontron Instruments). Injections were made in a $50 \mu \mathrm{l}$ injection valve (Model 7161, Rheodyne, Cotaty, USA) with a $100 \mu \mathrm{l}$ syringe from Hamilton (Bonaduz, Switzerland). The calibration method used ubiquinone as external standard. The within-run coefficients of variation for $\mathrm{CoQ}_{10}$ and $\mathrm{CoQH}_{2}$ were, respectively, 5 and $3.2 \%$, and the day to day precisions were 9.2 and $6.3 \%$. $\mathrm{CoQ}_{10}$ recovery ranged between 88 and $93 \%$. The measurements of $\mathrm{CoQ}_{10}$ were expressed in $\mathrm{nmol} / \mathrm{g}$ of protein. The measures were performed three times for every sample.

\section{Statistical analysis}

Results were expressed as mean \pm SD. Statistical analysis was done by the SPSS statistical package (15.0 version). For continuous variables the Kolmogorov-Smirnoff test was used to analyze normality in the distribution. Then, the Students's two-sample t-test was used for variables that followed a normal distribution and the Mann-Whitney test was used for the rest of variables. The results of each table were corrected for multiple comparisons by the use of Bonferroni's correction. Correlation analyses were performed by using Pearson's correlation coefficient.

\section{Results}

The results are summarized in tables 2 and 3 . When compared with controls, PD patients showed significantly lower specific activities for complex V (both corrected by citrate synthase activity and protein concentrations, table 2, figure 1). Oxidized, reduced and total coenzyme Q10 levels (both corrected by citrate synthase and protein concentrations), and activities of total, $\mathrm{Cu} / \mathrm{Zn}$ - and $\mathrm{Mn}$-superoxide-dismutase, gluthatione-peroxidase and catalase, did not differ significantly between PD-patients and control groups (table 3). Values for enzyme activities in the PD group did not correlate with age at onset, duration, scores of the Unified Parkinson's Disease Rating scales and Hoehn-Yahr staging.

Table 3 Mean (SD) superoxide-dismutase (SOD), glutathione-peroxidase (GPX), and catalase activities (expressed as units/mg protein); and concentrations of coenzyme $Q_{10}$ (expressed in $\mathbf{n m o l} / \mathrm{g}$ protein) in skin fibroblast cultures of patients with Parkinson's disease (PD) and controls (CS = citrate synthase).

\begin{tabular}{|c|c|c|c|}
\hline VARIABLE & $\begin{array}{l}\text { PARKINSON'S DISEASE } \\
(n=20)\end{array}$ & $\begin{array}{l}\text { CONTROLS (n } \\
=19)\end{array}$ & $\begin{array}{l}p \\
\text { values }\end{array}$ \\
\hline REDUCED CoQ10/CS & $0.41(0.16)$ & $0.34(0.11)$ & n.s. \\
\hline OXIDIZED CoQ10/CS & $0.75(0.26)$ & $0.63(0.23)$ & n.s. \\
\hline TOTAL CoQ10/CS & $1.16(0.33)$ & $0.97(0.25)$ & n.s. \\
\hline $\begin{array}{l}\text { REDUCED CoQ10/ } \\
\text { protein }\end{array}$ & $24.50(7.38)$ & $24.50(7.38)$ & n.s. \\
\hline $\begin{array}{l}\text { OXIDIZED CoQ10/ } \\
\text { protein }\end{array}$ & $56.49(25.20)$ & $47.31(23.50)$ & n.s. \\
\hline $\begin{array}{l}\text { TOTAL CoQ10/ } \\
\text { protein }\end{array}$ & $86.27(29.07)$ & $71.86(26.38)$ & n.s. \\
\hline $\begin{array}{l}\text { OXIDIZED Q10/ } \\
\text { Reduced Q10 }\end{array}$ & $0.60(0.27)$ & $0.62(0.27)$ & n.s. \\
\hline MnSOD/protein & $14.20(8.84)$ & $11.76(7.88)$ & n.s. \\
\hline CuZnSOD/protein & $8.80(7.08)$ & $8.90(6.87)$ & n.s. \\
\hline TOTAL SOD/protein & $26.00(8.58)$ & $20.72(11.52)$ & n.s. \\
\hline GPx/protein & $13.03(4.96)$ & $14.45(6.47)$ & n.s. \\
\hline CATALASE/protein & $9.71(5.20)$ & $7.26(2.05)$ & n.s. \\
\hline
\end{tabular}




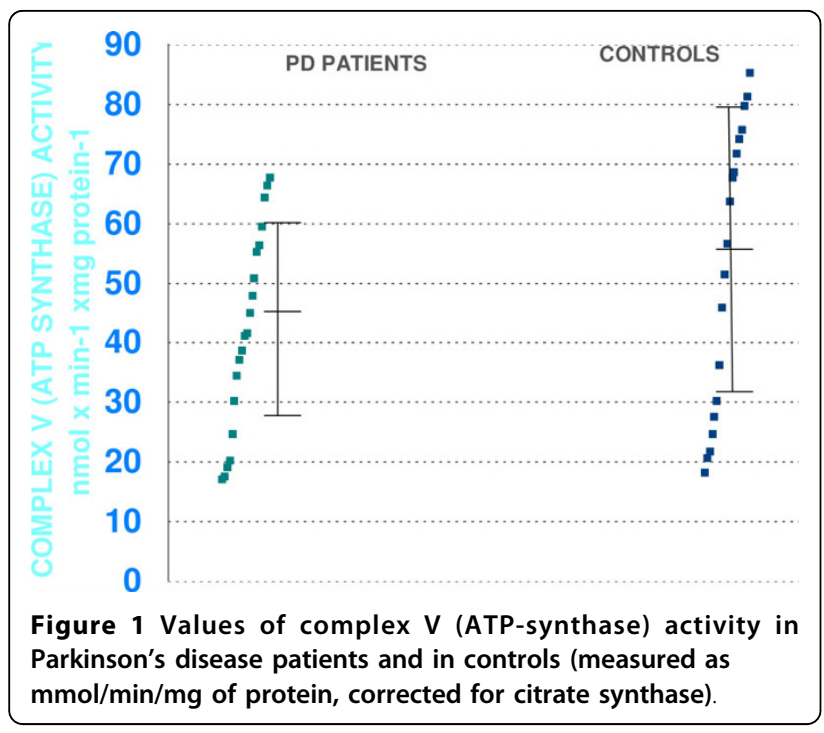

\section{Discussion}

The results of the present study showed that in PD patients there was a decreased activity of mitochondrial respiratory chain complex $\mathrm{V}$, corrected by CS activity, in skin fibroblast cultures. The results on complexes I and IV in this study did not differ significantly between PD patients and control groups, and none of our patients showed decreased activities of these complexes. These results contrast with those reported by other group $[32,33]$, who found a deficiency in complexes I and IV activities, specially in a subgroup of PD patients compared with controls, using skin fibroblast cultures as well. This deficiency was partially restored with coenzyme $\mathrm{Q}_{10}$ treatment [33].

The discrepancies between the results on complex I and IV of the present study and those of Winkler-Stuck et al. $[32,33]$ could be related with several methodological reasons. These authors found enhanced flux control coefficient of complex I and IV. This kind of variation was measured using inhibitor titrations and calculating the flux control coefficients from titration curves. The method used by Winkler-Stuck et al. [32,33] is different from that used in our study, because we only have measured, in the case of mitochondrial respiratory chain complex activities, the activity of every complex, and not the flux control coefficient. In addition, the control groups were different, because while Winkler-Stuck et al. $[32,33]$ included patients who performed muscle biopsy because they had discrete myopathic EMG abnormalities but withoutt biopsy evidence of myopathy, while our control patients had no clinical symptoms or signs suggesting myopathy. Winkler-Stuck et al. [32,33] did not measure complex $\mathrm{V}$ activity.

Our results suggest that decreased complex I activity seen in the substantia nigra of PD patients is not a generalised phenomenon. It is of note that complex $\mathrm{V}$ has not been usually studied neither in brain nor in peripheral tissues from PD patients. Indeed, complex V was not measured in previous studies by our group using isolated mitochondria from lymphocytes [27] or spermatozoa [31] or in other report using skin fibroblasts [32,33]. Cardellach et al. [15] found decreased complex $\mathrm{V}$ activity in muscle of 2 out of their 8 parkinsonian patients and, more recently, Ferrer et al. [35] found decreased levels of ATP-synthase (complex V) in the substantia nigra and increased levels of this enzymatic complex in the frontal cortex of patients with PD.

The activities of $\mathrm{Cu} / \mathrm{Zn}$ - and Mn-SOD, GPx, and catalase, and the oxidized, reduced, and total $\mathrm{CoQ}_{10}$ levels in skin fibroblasts of PD patients were similar to those of controls. To our knowledge, these values have not been previously measured in this tissue form, with the exception of the single patient with a mutation in the PINK1 gene reported by Piccoli et al. [34]. These results do not rule out the possibility that there may be regional deficiencies of the activities of these enzymes and of $\mathrm{CoQ}_{10}$ concentrations in some areas of the brain. Moreover, none of the enzymatic activities measured was correlated with the analyzed clinical features of PD.

\section{Conclusions}

The main result of the present study in skin fibroblasts cultures suggests a possible contribution of the deficiency of complex $\mathrm{V}$ activity, but not of other enzymes related with oxidative stress, to the pathogenesis of PD. This result is in agreement with that reported by Ferrer et al [35] in the PD substantia nigra, which was interpreted by the authors as related with neuronal loss. Complex $\mathrm{V}$ is involved in the synthesis of ATP from ADP, and is very important in the energetic metabolism of the cells. The result of the present study suggests decreased energetic metabolism in fibroblasts of patients with PD.

\section{Acknowledgements \\ This work was supported in part by the grant of the Fondo de Investigaciones Sanitarias 99/0518 and Neuro-Magister S.L.U.}

\section{Author details}

'Departamento de Bioquímica - Investigación, Hospital Universitario Doce de Octubre, Madrid, Spain. ${ }^{2}$ Servicio de Bioquímica, Hospital Nuestra Señora del Prado, Talavera de la Reina, Toledo, Spain. ${ }^{3}$ Servicio de Neurología, Hospital Universitario Doce de Octubre, Madrid, Spain. ${ }^{4}$ Departamento de MedicinaNeurología. Hospital. "Príncipe de Asturias", Universidad de Alcalá, Alcalá de Henares, Madrid, Spain. ${ }^{5}$ Sección de Neurología, Hospital La Mancha-Centro, Alcázar de San Juan, Ciudad Real, Spain. ${ }^{6}$ Departamento de Farmacología y Psiquiatría, Universidad de Extremadura, Badajoz, Spain. ${ }^{7}$ Sección de Neurología, Hospital del Sureste, Arganda del Rey, Madrid, Spain.

\section{Authors' contributions}

(all authors read and approved the final manuscript)

- PDH participated in the conception and design of the study, in the obtention of fibroblast cultures, biochemical analysis, drafting and critical revision of the manuscript, and supervision. 
- AGR participated in the conception and design of the study, in the obtention of fibroblast cultures, biochemical analysis, drafting and critical revision of the manuscript, and supervision.

- FDB participated in the conception and design of the study, in the obtention of fibroblast cultures, biochemical analysis, drafting and critical revision of the manuscript, and supervision.

- JAM participated in the conception and design of the study, in the recruitment and clinical evaluation of patients and controls, drafting and critical revision of the manuscript, obtaining funding, and supervision. - YS participated in the conception and design of the study, in the recruitment and clinical evaluation of patients and controls, and drafting and critical revision of the manuscript.

- HAN participated in the conception and design of the study, in the recruitment and clinical evaluation of patients and controls, and drafting and critical revision of the manuscript.

- LC participated in the conception and design or the study, and drafting and critical revision of the manuscript.

- JA participated in the conception and design or the study, drafting and critical revision of the manuscript, and supervision.

- JAGA participated in the conception and design of the study, performed statistical analysis, participated in the drafting and critical revision of the manuscript, and supervision.

- FJJJ participated in the conception and design of the study, in the recruitment and clinical evaluation of patients and controls, drafting and critical revision of the manuscript, obtaining funding, and supervision.

\section{Competing interests}

The authors declare that they have no competing interests.

Received: 30 March 2010 Accepted: 19 October 2010

Published: 19 October 2010

\section{References}

1. Nicklas WJ, Vyas I, Heikkila RE: Inhibition of NADH-linked oxidation in brain mitochondria by 1-methyl-4-phenylpyridine, a metabolite of the neurotoxin, 1-methyl-4-phenyl-1,2,3,6-tetrahydropyridine. Life Sciences 1985, 36:2503-2508.

2. Vyas I, Heikkila RE, Nicklas WJ: Studies on the neurotoxicity of 1-methyl-4phenyl-1,2,3,6-tetrahydropyridine: inhibition of NAD-linked substrate oxidation by its metabolite, 1-methyl-4-phenyl-pyridinium. Journal of Neurochemistry 1986, 46:1501-1507.

3. Mizuno $Y$, Saitoh T, Sone N: Inhibition of mitochondrial NADH-ubiquinone oxidoreductase activity by 1-methyl-4-phenylpyridinium ion. Biochemical and Biophysica. Research Communications 1987, 143:294-299.

4. Alonso-Navarro H, Jiménez-Jiménez FJ, Pilo de la Fuente B, Plaza-Nieto JF: Mecanismos patogénicos de la enfermedad de Parkinson. In Tratado de los Trastornos del Movimiento. 2nd edition (ISBN 978-84-85424-76-4). Edited by: Jiménez-Jiménez FJ, Luquin MR, Molina JA, Linazasoro G. Barcelona: Viguera Editores S.L; 2008:425-485.

5. Parker WD Jr, Parks JK, Swerdlow RH: Complex I deficiency in Parkinson's disease frontal cortex. Brain Research 2008, 1189:215-218.

6. Mann V, Cooper JM, Krige D, Daniel SE, Schapira AH, Marsden CD: Brain, skeletal muscle and platelet homogenate mitochondrial function in Parkinson's disease. Brain 1992, 115:333-342.

7. Anderson JJ, Bravi D, Ferrari R, Davis TL, Baronti F, Chase TN, Dagani F: No evidence for altered mitochondrial function in Parkinson's disease. Journal of Neurology, Neurosurgery, and Psychiatry 1993, 56:477-480.

8. Di Donato S, Zeviani M, Giovannini P, Savarese N, Rimoldi M, Mariotti C, Girotti F, Caraceni T: Respiratory chain and mitochondrial DNA in muscle and brain in Parkinson's disease patients. Neurology 1993, 43:2262-2268.

9. Di Monte DA, Sandy MS, Jewell SA, Langston JW: Oxidative phosphorylation by intact muscle mitochondrial function in Parkinson's disease. Neurodegeneration 1993, 2:275-281.

10. Reichmann H, Janetzky B, Bischop F, Seibel P, Schöls L, Kuhn W, Przuntek H: Unaltered respiratory chain enzyme activity and mitochondrial DNA in skeletal muscle of patients with idiopathic Parkinson's syndrome. European Neurology 1994, 34:263-267.

11. Bindoff LA, Birch-Machin M, Cartlidge NE, Parker WD Jr, Turnbull DM: Mitochondrial function in Parkinson's disease. The Lancet 1989, 2:49.
12. Bindoff $L A$, Birch-Machin M, Cartlidge NE, Parker WD Jr, Turnbull DM: Respiratory chain abnormalities in skeletal muscle from patients with Parkinson's disease. Journal of the Neurological Sciences 1991, 104:203-208.

13. Nakagawa-Hattori Y, Yoshino H, Kondo T, Mizuno Y, Horai S: Is Parkinson's disease a mitochondrial disease? Journal of the Neurological Sciences 1992, 107:29-33

14. Shoffner JM, Watts RL, Juncos JL, Torroni A, Wallace DC: Mitochondrial oxidative phosphorylation defects in Parkinson's disease. Annals of Neurology 1992, 32:226-227.

15. Cardellach F, Martí MJ, Fernández-Sola J, Marín C, Hoek B, Tolosa E, UrbanoMárquez A: Mitochondrial respiratory chain activity in skeletal muscle from patients with Parkinson's disease. Neurology 1993, 43:2258-2262.

16. Blin O, Desnuelle C, Rascol O, Borg M, Peyro-Saint Paul H, Azulay JP, Bille F, Figarella D, Coulom F, Pellissier JF, et al: Mitochondrial respiratory failure in skeletal muscle from patients with Parkinson's disease and multiple system atrophy. Journal of the Neurological Sciences 1994, 125:95-101.

17. Winkler-Stuck K, Kirches E, Mawrin C, Dietzmann K, Lins H, Wallesch CW, Kunz WS, Wiedemann FR: Re-evaluation of the dysfunction of mitochondrial respiratory chain in skeletal muscle of patients with Parkinson's disease. Journal of Neural Transmission 2005, 112:499-518.

18. Bravi D, Anderson JJ, Dagani F, Davis TL, Ferrari R, Gillespie M, Chase TN: Effect of aging and dopaminomimetic therapy on mitochondrial respiratory function in Parkinson's disease. Movement Disorders 1992, 7:228-231.

19. Blake Cl, Spitz E, Leehey M, Hoffer BJ, Boyson SJ: Platelet mitochondrial respiratory chain function in Parkinson's disease. Movement Disorders 1997, 12:3-8.

20. Hanagasi HA, Ayribas D, Baysal K, Emre M: Mitochondrial complex I, II/III, and IV activities in familial and sporadic Parkinson's disease. International Journal of Neurosciences 2005, 115:479-493.

21. Parker WD, Boyson SJ, Parks JK: Abnormalities of the electron transport chain in idiopathic Parkinson's disease. Annals of Neurology 1989, 26:719-723.

22. Krige D, Carrol MT, Cooper JM, Marsden CD, Schapira AH: Platelet mitochondrial function in Parkinson's disease. The Royal Kings and Queens Parkinson Disease Research Group. Annals of Neurology 1992, 32:782-788.

23. Yoshino $\mathrm{H}$, Nakagawa-Hattori $\mathrm{Y}$, Kondo T, Mizuno $\mathrm{Y}$ : Mitochondrial complex I and II activities of lymphocytes and platelets in Parkinson's disease. Journal of Neural Transmission (Parkinson's Disease Section) 1992, 4:27-34.

24. Benecke R, Strumper P, Weiss H: Electron transfer complexes I and IV of platelets are abnormal in Parkinson's disease but normal in Parkinsonplus syndromes. Brain 1992, 116:1451-1463.

25. Haas RH, Nasirian F, Nakano K, Ward D, Pay M, Hill R, Shults CW: Low platelet mitochondrial complex I and complex II/III activity in early untreated Parkinson's disease. Annals of Neurology 1995, 37:714-722.

26. Varghese M, Pandey M, Samanta A, Gangopadhyay PK, Mohanakumar KP: Reduced NADH coenzyme $\mathrm{Q}$ dehydrogenase activity in platelets of Parkinson's disease, but not Parkinson plus patients, from an Indian population. Journal of the Neurological Sciences 2009, 279:39-42.

27. Barroso N, Campos Y, Huertas R, Esteban J, Molina JA, Alonso A, GutiérrezRivas $E$, Arenas J: Respiratory chain enzyme activities in lymphocytes from untreated patients with Parkinson disease. Clinical Chemistry 1993, 39:667-669.

28. Martín MA, Molina JA, Jiménez-Jiménez FJ, Benito-León J, Ortí-Pareja M, Campos Y, Arenas J, Grupo Centro de Trastornos del Movimiento: Respiratory chain enzyme activities in isolated mitochondria of lymphocytes from untreated Parkinson's disease patients. Neurology 1996, 46:1343-1346.

29. Shinde S, Pasupathy K: Respiratory-chain enzyme activities in isolated mitochondria of lymphocytes from patients with Parkinson's disease: preliminary study. Neurology India 2006, 54:390-393.

30. Muftuoglu M, Elibol B, Dalmizrak O, Ercan A, Kulaksiz G, Ogus H, Dalkara T, Ozer N: Mitochondrial complex I and IV activities in leukocytes from patients with parkin mutations. Movement Disorders 2004, 19:544-548.

31. Molina JA, Ruiz-Pesini E, Jiménez-Jiménez FJ, López-Pérez MJ, Alvarez E, Berbel A, Ortí-Pareja M, Zurdo M, Tallón-Barranco A, de Bustos F, Arenas J: Respiratory chain enzyme activity in spermatozoa from untreated Parkinson's disease patients. Journal of Neural Transmission 1999, 106:919-924. 
32. Wiedemann FR, Winkler K, Lins H, Wallesch CW, Kunz WS: Detection of respiratory chain defects in cultivated skin fibroblasts and skeletal muscle of patients with Parkinson's disease. Annals of the New York Academy of Sciences 1999, 893:426-429.

33. Winkler-Stuck K, Wiedemann FR, Wallesch CW, Kunz WS: Effect of coenzyme $Q_{10}$ on the mitochondrial function of skin fibroblasts from Parkinson patients. Journal of the Neurological Sciences 2004, 220:41-48.

34. Piccoli C, Sardanelli A, Scrima R, Ripoli M, Quarato G, D'Aprile A, Bellomo F, Scacco S, De Michele G, Filla A, luso A, Boffoli D, Capitanio N, Papa S: Mitochondrial respiratory dysfunction in familiar parkinsonism associated with PINK1 mutation. Neurochemical Research 2008, 33:2565-2574.

35. Ferrer I, Pérez E, Dalfó E, Barrachina M: Abnormal levels of prohibitin and ATP synthase in the substantia nigra and frontal cortex in Parkinson's disease. Neuroscience Letters 2007, 415:205-209.

36. Schapira AHV: Mitochondria in the aetiology and pathogenesis of Parkinson's disease. Lancet Neurology 2008, 7:97-109.

37. Ambani LM, Van Woert MH, Murphy S: Brain peroxidase and catalase in Parkinson disease. Archives of Neurology 1975, 32:114-118.

38. Kish SJ, Morito C, Hornykiewicz O: Glutathione peroxidase activity in Parkinson's disease. Neuroscience Letters 1985, 58:343-346.

39. Marttila RJ, Lorentz H, Rinne UK: Oxygen toxicity protecting enzymes in Parkinson's disease: increase of superoxide dismutase-like activity in the substantia nigra and basal nucleus. Journal of the Neurological Sciences 1988, 86:321-331.

40. Saggu H, Cooksey J, Dexter D, Wells FR, Lees A, Jenner P, Marsden CD: A selective increase in particulate superoxide dismutase activity in parkinsonian substantia nigra. Journal of Neurochemistry 1989, 53:692-697.

41. Choi J, Rees HD, Weintraub ST, Levey Al, Chin LS, Li L: Oxidative modifications and aggregation of $\mathrm{Cu}, \mathrm{Zn}$-superoxide dismutase associated with Alzheimer and Parkinson disease. Journal of Biological Chemistry 2005, 280:11648-11655.

42. Radunovic A, Porto WG, Zeman S, Leigh PN: Increased mitochondrial superoxide dismutase activity in Parkinson's disease but not amyotrophic lateral sclerosis motor cortex. Neuroscience Letters 1997 239:105-108.

43. Ernster L, Dallner G: Biochemical, physiological and medical aspects of ubiquinone function. Annals of Neurology 1995, 42:261-264.

44. Shults $C Q$, Haas RH, Passov D, Beal MF: Coenzyme $Q_{10}$ levels correlate with the activities of complexes I and II/III mitochondria from parkinsonian and nonparkinsonian patients. Annals of Neurology 1997, 42:261-264.

45. Gotz ME, Gerstner A, Harth R, Dirr A, Janetzky B, Kuhn W, Riederer P, Gerlach M: Altered redox state of platelet coenzyme $Q_{10}$ in Parkinson's disease. Journal of Neural Transmission 2000, 107:41-48.

46. Zheng X, Shoffner JM, Voljavec AS, Wallace DC: Evaluation of procedures for assaying oxidative phosphorylation enzyme activies in mitochondrial myopathy muscle biopsies. Biochimica Biophysica Acta 1990, 101:1-10.

47. Lowry OH, Rosebrough NJ, Farr AL, Randall RS: Protein measurement with the Folin phenlo reagent. Journal of Biological Chemistry 1951, 193:265-271.

48. Flohé L, Günzler W: Assays of glutathione peroxidase. Methods in Enzymology 1984, 105:114-121.

49. Aebi H: Catalase in vitro. Methods in Enzymology 1984, 105:121-126.

50. Spitz DR, Oberley LW: An assay for superoxide dismutase activity in mammalian tissue homogenates. Analitical Biochemistry 1989, 179:8-18.

51. Langedijk J, Ubbink JB, Vermaak WJH: Measurement of the ratio between the reduced and oxidized forms of coenzyme $Q_{10}$ in human plasma as a possible marker of oxidative stress. Journal of Lipid Research 1996, 37:67-75.

\section{Pre-publication history}

The pre-publication history for this paper can be accessed here: http://www.biomedcentral.com/1471-2377/10/95/prepub

doi:10.1186/1471-2377-10-95

Cite this article as: del Hoyo et al:: Oxidative stress in skin fibroblasts cultures from patients with Parkinson's disease. BMC Neurology 2010 10:95.

\section{Submit your next manuscript to BioMed Central and take full advantage of:}

- Convenient online submission

- Thorough peer review

- No space constraints or color figure charges

- Immediate publication on acceptance

- Inclusion in PubMed, CAS, Scopus and Google Scholar

- Research which is freely available for redistribution

Submit your manuscript at www.biomedcentral.com/submit
Biomed Central 